\title{
LOCAL POLITICAL PARTIES IN ACEH IN 2017 REGIONAL ELECTION: Analysis of Political Identity and Islamization Issue
}

\author{
Muhammad Rajiv Syarif \\ International Islamic University, Malaysia \\ E-mail: rajiev.syarif@gmail.com
}

\begin{abstract}
The existence of local political parties in outline is a new alternative to the implementation of local democratic processes in Aceh are not specifically for Islamization issues. In the political record, the process of electing leaders in Aceh Province has been noted for three times (2006, 2012 and 2017). Aceh continues to move dynamically with political activities that are often rarely predictable or new conflicts that are sometimes expected to occur during democratic parties. This paper examines factors of voter's behavior and political identity in Aceh after the signing peace agreement in 2005 as well as analyzes the regional elections in 2017 and the Islamization issue within it. It will be explained that the behavior of voters in the Aceh regional election is very crucial. The election runs successfully by playing the identity of the political party in the Islamic shari'a area bringing issues in local implementation's policy. Finally, the crisis of trust that has been happening to national political parties has become one of the benchmarks for people to participate in the implementation of local democracy through the emergence of local political parties in Aceh.
\end{abstract}

Keberadaan partai politik lokal secara garis besar merupakan alternatif baru untuk pelaksanaan proses demokrasi lokal di Aceh tidak secara khusus untuk masalah Islamisasi. Dalam catatan politik yang ada, proses 
pemilihan pemimpin di Provinsi Aceh telah dicatat selama tiga kali (2006, 2012 dan 2017). Aceh terus bergerak secara dinamis dengan kegiatan politik yang sering kali jarang dapat diprediksi atau konflik baru yang kadang diharapkan terjadi selama Partai Demokrat. Artikel ini meneliti faktor perilaku pemilih dan identitas politik di Aceh setelah penandatanganan perjanjian perdamaian di 2005 serta menganalisis pemilu daerah di 2017 dan isu Islamisasi di dalamnya. Akan dijelaskan bahwa perilaku pemilih dalam Pilkada Aceh sangat krusial. Pemilu ini berjalan baik dengan memainkan identitas partai politik di daerah Syari'at Islam yang membawa persoalan dalam kebijakan pelaksana daerah. Akhimya, krisis kepercayaan yang telah terjadi pada partai politik nasional menjadi salah satu tolok ukur bagi masyarakat untuk ikut serta dalam pelaksanaan demokrasi lokal melalui munculnya partai politik lokal di Aceh.

Keywords: Islamization; political identity; local political party; voters behavior

Received: October 29, 2018; Accepted: December 11, 2019

\section{Introduction}

Aceh is a province located in the northern part of Sumatra Island which has a privileged status in its politics. This privileged status was achieved by Aceh following the peace agreement between the Indonesian government and the Free Aceh Movement on 15 August 2005 in Helsinki, Finland. Aceh was formerly known as the tip of Indonesia which experienced separatist conflict that wanted independence for Aceh as an independent country. In the meantime, it is also famous as a region hit by the greatest disaster in the modern age where in 2004 there was a Tsunami that killed more than two hundred thousand people.

Nowadays, it has been more than a decade Aceh as a special autonomous region since the enactment of Law Number 11 Year 2006 regarding the Aceh Government (LoGA). Furthermore, following the enactment of the LoGA in Aceh, it has legally granted the title as a special region for post-conflict political recognition and promoting peaceful conditions in the life of the Acehnese people. The Acehnese had re-elected leaders both at the level of the Governor and Vice-Governor, as well as the regents/vice-mayors/vice-mayors in 2017. It can be seen from the Acehnese 
people's desire that they still rely on local elections to the regions or Pilkada 2017 in determining leaders and the future of Aceh.

In the political record, the process of electing leaders in Aceh Province has been noted for three times (2006, 2012 and 2017). Moreover, Aceh continues to move dynamically with political activities that are often rarely predictable or new conflicts that are sometimes expected to occur during democratic parties. This is evident from the last two local elections that there is a difference in the voter's behavior that determines their political choices between 2012 and 2017 elections. In 2012, the result of the elections of Aceh Governor and Deputy Governor for the period 2012 2017 conducted by the Commission of Independent Election or Komisi Independen Pemilihan in Aceh Parliament, Tuesday (17/4) put the couple dr $\mathrm{H}$ Zaini Abdullah and Muzakir Manaf as winning the most votes and at the same time made the couple from the Aceh Party (PA) as governor/deputy governor-elect.

Five years later, in 2017 the province of Aceh once again conducts a political process of elections to re-determine who is elected as the governor of Aceh in the period 2017 to 2022. Participation of the voters increased (73\%) to participate in the political agenda in Aceh especially in the local elections in 2017 (Pilkada 2017 Lebih Baik dari Sebelumnya 2017). In this year's election, there is a new local political party in Aceh that nominates the pair candidate of governor namely Irwandi Yusuf and Nova Iriansyah. The name of this political party is Partai Nasional Aceh (PNA) or the Aceh National Party. Aceh National Party is one of the local political parties in the province of Aceh, Indonesia. The political party has participated in the 2014 Indonesian legislative elections and the election of members of the Aceh Provincial Parliament. Former Aceh Governor Irwandi Yusuf founded the party on April 24.

Based on the two facts above, there are several points to be noted that the two elections in 2012 and 2017 Acehnese people are confronted with two different outcomes in their election results. In 2012, voters tend to set their choices on candidates from Partai Aceh (PA) namely Zaini Abdullah and Muzakkir Manaf. Meanwhile, voters shifted in 2017 and made their choice in Aceh National Party (PNA) candidate, Irwandi Yusuf, and Nova Iriansyah. Thus, the Indonesian government at that time successfully crushed the plan.

This paper examines factors of voter's behavior and political identity in Aceh after the signing peace agreement in 2005 as well as analyzes the 
regional elections in 2017 as well as the Islamization issue within it. Identity politics is the politics in which people engage when they mobilize based on, and when they define their experiences, their political problems, and their aims in terms of the good of identity-groups (Jati 2012). Historically, identity politics grew out of the experience of identity-based oppression: the experience of inequalities in resources and opportunities that people encountered as members of particular identity groups (Hayward and Watson 2010).

Five-year political agenda that has been implemented in Indonesia especially in Aceh is a fact that presents the phenomenon of varied competition in terms of local election. The existence of governor candidates with different political backgrounds makes the election results need to be observed further. In 2012 it is recorded the winner of Local Election in Aceh is from Partai Aceh (PA) while in 2017 National Party of Aceh (PNA) winning this election. Thus, the political party in Aceh is considered playing significant rule as the identity of voters during two seasons of elections in 2012 and 2017.

The existence of conflict for more than 30 years in Aceh affected the situation and political environment at that time. This produced a fact that there were causes, which attempted to face two different bodies which are Gerakan Aceh Merdeka (GAM) Free Aceh Movement and Government of Indonesia. Next, based on this fact, the political dynamics of Aceh are very volatile especially after the peace agreement in 2005 between the two conflicting blocs in Helsinki. The result was a proven political process in the 2007 elections indicating that for the first time Aceh made history by winning a pair of candidates for governors and deputy governors from nonpolitical parties or independent backgrounds. Hence, there is an exact change in the following elections as well as in 2012 and 2017.

This paper is a very popular discussion whereas - in my searching there is no research on the local politics of Aceh which examines the behavior of voters in the last elections (Husna 2017; Aspinall and Mas'udi 2017; Januar 2018; Nur, Usman, and Safwadi 2018; Alwy and Febriandi 2018). It will be very comprehensive and valuable if the disclosure of this title. Hopefully, it can be helped by the researchers who are focusing on the topic of behavioral issues regarding the local election. 


\section{The Literature of Elections in Indonesia}

Elections are one of the characteristics that should exist in a democratic country. Thus the election is an important tool for people in the life of the state choosing representatives in charge as the official government. A general election is held in an atmosphere of openness to freedom of speech and freedom of association, thought to reflect fairly accurately reflect the aspirations and participation community (Budiardjo 2008).

According to Article number 1 Paragraph (1) of the Law of the Republic of Indonesia Number 3 of 1999 on General Elections, elections are a means of implementation of the sovereignty of the people within the unitary Republic of Indonesia based on Pancasila and the 1945 Constitution. Haris G. Warren, as cited by Ramlan Surbakti, said that the election is an opportunity for residents of the state to select government officially and decide whether it is done by the government. Moreover, in making the decision, the citizens determine what exactly they want to have (Surbakti 1992). Meanwhile, according to A. Sudiharto, the election is an important means of democracy and a real manifestation of people's participation in national life.

Based on these opinions, it can be said that the election is a way of determining the representatives who will run the government. The elections must be accompanied by freedom or no influence as well as pressure from any party. The higher the level of freedom in the elections the better the elections. It leads to the assumption that the more people who participate in the elections, the higher level of democracy contained in holding elections.

\section{Regional Election in Indonesia}

Regional Election that abbreviated to be Pemilukada or Pemilihan Umum Kepala Daerah became the national political consensus which is one of the important instruments of governance after the rolling out of regional autonomy in Indonesia by choosing a Governor and Vice Governor for 5 year period of leadership. This is based on Article 43 Paragraph (3) of Law Number 22 in 2007 concerning the "Implementation of General Election." While Indonesia itself has conducted direct election since the enactment of Law of the Republic of Indonesia Number 32 Year 2004 on Regional Government. 
When viewed from the perspective of decentralization, the direct election is a significant breakthrough for the process of democratic consolidation at the local level. Pemilukada will soon open up a wider space of participation for the community in the democratic process to determine political leadership at the local level. This system also opens the opportunity for the public to actualize their political rights better without being reduced by the interests of the political elite, such as in the case of a representative democratic system.

Article 1 Paragraph (2) of Regulation of the General Election Commission Number 69 Year 2009 Concerning Technical Guidelines for the Election of Regional Head and Deputy Regional Head Elections defines the general election of regional head and deputy regional head, namely:

(2) Pemilihan Umum Kepala Daerah dan Wakil Kepala Daerah selanjutnya disebut Pemilu Kepala Daerah dan Wakil Kepala Daerah adalah Pemilu untuk memilih kepala daerah dan wakil kepala daerah secara langsung dalam Negara Kesatuan Republik Indonesia berdasarkan Pancasila dan Undang-Undang Dasar Negara Republik Indonesia Tahun 1945.

It can be explained that the General Election of Regional Head and Deputy Regional Head elects the regional head and deputy head of region directly in the Unitary State of the Republic of Indonesia based on Pancasila and the 1945 Constitution of the State of the Republic of Indonesia. Prior to the enactment of the Law of the Republic of Indonesia Number 32 Year 2004 on Regional Government, regional head and deputy head of region were elected by DPRD. However, since June 2005 Indonesia embraced the direct election system (Widjaja 2005).

The region is a part that cannot be separated from Indonesia. It is related to the election of regional head and deputy head of the region should sync with the presidential and vice-presidential election, namely direct election.

\section{Identity of Local Political Party}

Local political parties in Aceh are one of the tools for the democratization process that one of the mandates contained in the negotiations between the government of the Republic of Indonesia and the Free Aceh Movement or Gerakan Aceh Merdeka (GAM). It also poses a significant transformation of the separatist movement included in the frame of the homeland. It was also the evidence of transformation from 
combatants to politicians by the members of local political parties nowadays. Thus, it is the medium of politics in Aceh territory.

If it is examined by the history of Aceh conflict that takes more than 30 years, then it can be seen clearly that there are some problems demanded by the Aceh society in maintaining its political identity in the state. The beginning of the Aceh conflict arose from the disbelief of justice promised by Indonesia's first president Soekarno, who at that time Aceh itself willing to bargain to Indonesia and president Soekarno with the privilege of running the Islamic Shari'ah in kâffah. The demands eventually gave birth to a Darul Islam rebellion directed by Daud Beureueh who then served as governor of Aceh. Daud Bereueh stated that Aceh was part of the Indonesian Islamic State declared by Kartosuwiryo in western Java, but eventually the Indonesian government at that time successfully crushed the plan. The reason for Soekarno did not allow the implementation of Islamic Shari'a in Aceh because he was worried that other regions would also join the shari'a and break away from the Republic of Indonesia. Soekarno prefers the nationalist concept. According to him, more nationalists can unify differences such as ethnicity, religion, race, and ethnicity in Indonesia.

In the New Order era or Orde Baru, the insurgency resistance to independence is continued in 1976 by Hasan Tiro (a member of the Indonesian delegation to the United Nations in New York). He returned to Aceh and formed the Free Aceh Movement or known as Gerakan Aceh Merdeka to form a separatist movement from the Unitary State of the Republic of Indonesia. This was based on the disappointment of Acehnese society against the efforts of the exploration of natural resources conducted by the government of Indonesia that cannot be perceived directly to the community of Aceh. Gerakan Aceh Merdeka is established on December 4, 1976, at the camp coinciding in Cokan Hill, in tiro district, Pidie (Tiro 1999).

During the Soeharto period, GAM was seen as the Distortion Movement toward Security or Gerakan Pengacau Keamanan (GPK), and then it had to be eradicated. There was no reference during Soeharto's regime to make political integration efforts for this group. The military approach led to violence during the Territory of Military Operation or Daerah Operasi Militer (DOM) from 1989 to 1998 in Aceh. The disappearance of people, murder, rape, kidnapping, became an anti-thesis of the process of political 
integration during the New Order period due to the unfinished completion of the past and the failure of the approach in handling the separatism. On $7^{\text {th }}$ August 1998, General Wiranto as the Minister of National Defence as well as Commander of the National Army Forces announced the formal removal of the DOM in Aceh, but the condition of Aceh was getting more and more difficult.

The people in Aceh at that time wanted a referendum for themselves as given by B.J. Habibie in resolving the Timor Leste case, but the lawsuit received no response from the government. B.J. Habibie at that time provided the formulation for the Aceh people by giving the Islamic Shari'a specifically in Aceh as outlined in Law no. 44 of 1999, which regulates Aceh's special status. Article 1 states that the privilege of Aceh is a special authority to organize religious life, customs, education and the role of 'ulamâ in determining regional policy.

During the Megawati as Indonesia President, the idea of granting special autonomy was finally enacted through Law no. 18 of 2001 on Nanggroe Aceh Darussalam (NAD) and Islamic Shari'a. Further issues are Presidential Instruction, which contains six steps of instruction to resolve Aceh comprehensively in the political, economic, social, law and order, and security sectors but still not get satisfactory results.

In 2005, when Susilo Bambang Yudhoyono was elected as President of the Republic of Indonesia, the government succeeded in getting a peace agreement facilitated by the Crisis Management Initiative (CMI) led by former Finnish President Martti Ahtisaari who produced a Memorandum of Understanding (MoU) signed on 15 August 2005 between the Government of Indonesia and the Free Aceh Movement.

The Republic of Indonesia and the Free Aceh Movement chose to resolve the Aceh conflict in dignity. MoU Helsinki is a breakthrough by RI and GAM as one of the most fundamental transformation processes of conflict, from violent conflict to political struggle through a democracy framework. To achieve that, the transformation process will be carried out, as reflected in the contents of the memorandum of understanding through the administration of the Aceh government; political participation (local political party); economy; legislation; human rights (HAM), to the issue of amnesty and reintegration into society.

Local Political Party is nothing new in the history of state administration in Indonesia. The desire to form a local political party has been heard since the beginning of the reformation. At least the desire was 
based on the experience of the presence of local political parties in the 1955 General Election. That is, in the history of Indonesian state administration, something ahistorical. The proof, reflecting on the outcome of the 1955 General Election, there are many groups of political parties that get votes in the House of Representatives and Constituent Assembly. This last group can be categorized as a party or group of regional and tribal characters. For example, the emergence of Partai Rakyat Desa, Partai Rakyat Indonesia Merdeka, Sunda Selection Movement, Partai Tani Indonesia, and Banteng Movement in West Java. Furthermore, in other areas, there is Gerinda in Yogyakarta and the United Power Party in West Kalimantan.

Therefore, the presence of local political parties in Aceh is expected to become a vehicle for channeling the aspirations of the Acehnese people to achieve an efficient local democratic process. In brief, it is very important to know the roles of local parties that are expected to run its main functions to the maximum as expected by the people of Aceh especially in shaping the elections in 2017. Both Partai Aceh and Partai Nasional Aceh are known as the two main actors, which create a behavior of voters to vote for their rights at the elections. This kind of participation produces the identity local political party is still a choice by the constituency.

\section{Voters Behaviour toward Elections in Aceh}

An article written by Wojciech Cwalina, Andrzej Falkowski, and Bruce I. Newman were reinterpreting and testing empirically Newman's model of voter's choice behavior. Three elements influencing the choice of a given candidate were included: the media's role in the election; cognitive reasons to vote for; and emotional feelings toward the candidate. Furthermore, the key factor in influencing voting behavior in their research is evoking positive emotions towards the candidate and then providing voters with a justification for such effect. However, it is especially applicable in an evolving democracy like Poland. In an established democracy like the USA, voters have already learned to more carefully analyze messages from presidential campaigns and they are more resistant to the unconscious power of effect. Furthermore, in the case of challengers, the media exerts a stronger influence on the valuation of their candidacies, but for incumbents, the role of the media is not so pervasive (Cwalina, Falkowski, and Newman 2010).

The behavioral approach emerged and developed in the post-World War II period. The works of sociologist Max Weber and Talcott Parsons 
influence this movement, in addition to discoveries in the field of psychology. Political scholars renowned for this approach to political behavior are Gabriel A. Almond (structural-functional analysis), David Easton (general system analysis), Karl W. Deutsch (communications theory), David Truman, Robert Dahl, and so on. One of the main ideas of the pioneers of behavioral approaches is that political behavior, or power or political beliefs are defined as activities related to the process of making and executing political decisions (Budiardjo 2008).

Political behavior can be defined as the relationship between government and society, among governmental institutions and groups or individuals in society concerning the process of making, implementing and enforcing political decisions a political behavior (Surbakti 1992). According to Robert K Carl, political behavior is a study of human behavior in political situations (Surbakti 1992).

There are various studies of behavior and the determinants of victory and preference in elections. A research conducted by Thomas Meyer and Daniel Strobi shows that voters consider coalition formation and policy compromises at the post-electoral stage when making vote choices. Yet, it is known surprisingly little about how voters perceive policy positions of coalition governments (Meyer and Strobi 2016). Using new survey data from the Austrian National Election Study (AUTNES), it is found that voters do in general have reasonable expectations of the coalition's policy positions. However, partisan beliefs and uncertainty affect how voters perceive coalition positions: in addition to bias projections that are similar to those the placement of political parties partisans of coalition parties tend to align the position of the coalition with their own party's policy position, especially for those coalitions they prefer the most (Meyer and Strobi 2016).

It is certainly known that the political behavior of a person in dealing with election may vary from one to another. The things described earlier are some form of individual political behavior. To participate and join political parties is also a substitute for political behavior. This is because political parties are a means for citizens to participate in the process of managing the state and implementing policies for the state.

The behavior of voters in the Aceh regional election is very crucial because if the election runs successfully by playing the identity of a political party in the Islamic shari'a area bringing issues in local implementation's policy. Political behavior and voter political participation are an inseparable unity. Political behavior of voters is an important aspect in supporting the 
successful implementation of an election, especially in Aceh as the Islamic shari'a territory. The thing to be emphasized is the success of the implementation of the campaign by Partai Aceh and Partai Nasional Aceh, and the participation in the party and also the voting process or voting in elections especially local levels. In the struggle for this, the political party is like marketing a product or service to its target market.

If equated to trading, the target market for a political party is voters. If we clarify voters who are targeted by the political party market, then there will be 4 (four) types of potential voters. The first is the ideological voters, the second is the traditional voters, the third is rational voters who are divided into intellectual and non-partisan voters, and the fourth is the swing voters (Firmanzah 2007).

Harold d. Lasswell, as quoted by S.P. Varma, provides an important note about political behavior, there are five political behaviors. First, it is always value-oriented or trying to achieve goals. Values and goals are formed in the process of political behavior, which is one part. Second, political behavior aims to reach the future, anticipate, relate to the past, and always watch to the past events (Varma 2010)

Ramlan Surbakti mentioned that political behavior is an activity or action that pertains to or directly related to the political process, whether in political decision making to the implementation of political activity in the period. Two variables influence a person's political behavior in participating politics, namely awareness, and trust to the existing political elements. These variables are integrated into social status, economic status, political affiliation, and organizational experience. Consciousness is conscious of deeds (to the real state) the consciousness possessed by man is a unique form in which he can place himself by what he believes. Reflection is the expression of consciousness, in which it can give or survive in certain circumstances in an environment (Surbakti 1992).

\section{The Role of Mass Media in Shaping People's Argument}

These additional issues are brought because currently, media has shaped the opinion of the people in Aceh in terms of deciding their preferences in political parties. The role of the mass media is very important in influencing the political situation in Aceh. One of the main political rivalries is mass media. This mass media is defined as an entity that has roles and functions to collect and distribute information from and to society. The effectiveness of political communication requires the 
participation of the mass media because they are one of the professions important tools that have devices and the ability to communicate with the wider community. Political communication often occurs indirectly through media reports (Firmanzah 2007, 265).

In Aceh's case, there is a fact that the elections in 2012 and 2017 have a similar process of a political campaign called the theory of the new media environment. It is simply a definition that societies are increasingly connecting with political groups through new media technologies (Sweetser 2011), while social media have been touted as a pattern for engaging key stakeholder groups, disseminating campaign messages and increasing candidate support (LaMarre and Suzuki-Lambrecht 2013). However, few jobs to date have examined whether political campaigns can use social media effectively to meet their purposes and what role engagement with a campaign plays in the voting process (Housholder and LaMarre 2014).

\section{Influences of Local Political Parties}

This study uses the behavioral approach theory by Robert A Dahl. He cites Cf. Bernard Crick (Crick 1959) that, "The rapid flowering of the behavioral approach in the United States is not depended on the existence of some key attitudes and predispositions generated in the American culture-pragmatism, fact mindedness, confidence in science, and the like" (Dahl 1969).

Geographical aspects related to choosing behavior and Aceh as a province representing local geopolitics carrying the local issues for helping Acehnese society. The presence of a sense of regionalism affects one's support for a political party. Rose's studies in Norway, for example, show that regional bonds, such as urban villages, are significant factors in explaining one's political activities and choices. Regional ties are particularly strong in influencing one's choice of candidates (Asfar 2006, 140). In differences in social structure, the most influential effect on political behavior is the class factor (economic status).

Local political parties also have the same function as the function of political parties in general. The four functions of the political party are according to Miriam Budiardjo as political communication, political socialization, political recruitment, and conflict regulators (Budiarjo 2008). The four functions are equally interrelated to one another. As a political communication, the party was instrumental in the effort to articulate interests contained or sometimes hidden in society. These interests are best 
absorbed by political parties into the ideas, visions, and policies of the political parties concerned. After that, the ideas and policies or policy aspirations are advocated so that they can be expected to influence or even become official state policy material. In short, this idea is still relevant to why the identity of the political party in Aceh plays significant effects on elections.

Associated with political communication used by PA and PNA, both also play an important role in socializing politics. Idea, vision and strategic policy which become the choice of a political party are conveyed to constituents to get 'feedback' in the form of support from the public. Related to this political socialization, the party also plays a very important role in the framework of political education. Party is the intermediate structure or intermediate structure that must play a role in grounding the ideals of the state in the collective consciousness of citizens.

The function of the three political parties is a means of political recruitment. The Party was formed indeed intended to be a legitimate vehicle for selecting cadres of state leaders at certain levels and positions. The cadres are directly elected by the people, some are elected by indirect means, such by the House of Representatives, or through other indirect means. In this case, the regeneration of the member of the political party in Aceh is chosen in terms of the involvement of a person in a conflict in the past. It can be said that this is the transformational movement from the separatist movements to political movement which both are still powerful actors in Aceh.

The fourth function is the organizers and managers of conflicts that occur in the community. Values and interests which grew in the lives of people are very diverse, complex, and tend to compete with each other and collide with one another. If there are many political parties, these diverse interests can be channeled through the polarization of political parties that offer different ideologies, programs, and alternative policies. In other words, as a party regulator or manager of a conflict, it serves as a means of aggregating interests that channel the different interests through the party's political channels.

The existence of local political parties is one proof of local democracy running in Aceh. Local democracy has many meanings, depending on space and place, and indeed none of the concepts or models can be regarded as the best manifestation of democracy. However, there is a general understanding that democracy requires the same respect and 
protection of the most basic civil and political rights. Thus, in local democracy, local people also have civil and political rights, one of which is the establishment of local political parties and definitely will vote for them because these parties bring the local problems to be solved and discussed.

Within the framework of local democracy, local political parties have an important role: to carry out all forms of local democracy which is a basic feature of the formation of the local party itself. The election of Pilkada as a manifestation of local democracy is very appropriate to encourage the dynamics and change of public life in Aceh. Therefore, the existence of local political parties is expected to make local democracy run properly with implementation to better social welfare so that the discourse on the implementation of efficient governance can be implemented by following the mandate contained in MoU Helsinki.

\section{The challenges of Islamization within Local Political Party}

Islamization is a reality of the functioning of political parties in Aceh which has not run optimally, especially the function of political aggregation and political education media as the most important function. A critic generally known that politicians tend to exhibit a glamorous lifestyle with more emphasis on purely political activities not to input the value of Islam for local political parties. They are still seen as ahead of the five-year cycle, namely the election.

The political parties in the local region, especially in Aceh's case, is recognized particularly in bringing Islamic value automatically. This because of the province of Islamic shari'a law even though there is specifically a local political party in Aceh based on Islamic background which is Partai Daulah Aceh. Therefore, it is clear that it has to be understood formally that Partai Aceh and Partai Nasional Aceh are implementing Islamic value, but it is not mentioned clearly by its names. The people in Aceh historically are known as the society who applied Islamic values since the independence of the Republic Indonesia itself because the Kingdom of Aceh Darussalam is one of the largest Islamic Empires at that time.

Another example of an unseemly parochial role is when members of parliament are busy criticizing the executive's performance but when the policy is linked to the elite interests of political parties in parliament it is as if the commotion is lost and replaced by a very striking silence. Not to mention the presence of Legislative Heavy era where the balance of parliamentary authority is stronger than the Executive to make 
coordination of the institution does not run intact with the local democratic process in Aceh.

Meanwhile, some hopes want the local political parties to be consistent with their purposes which are bringing the welfare in Aceh rapidly. Its existence is a bright spot from the darkness of the conflict that has occurred for about 32 years. Both Partai Aceh (PA) and Partai Nasional Aceh (PNA) have an important role for the process of political education for the people of Aceh in particular; they must provide education to all elements of Acehnese society as well to reconstruct the combatants of conflict during the 32 years historical trauma.

\section{Conclusion}

It can be summarized that the existence of local political parties in outline is a new alternative to the implementation of local democratic processes in Aceh not specifically for Islamization issues. This can also be seen from the increased (73\%) participation of the voters to participate in the political agenda in Aceh especially in the local elections in 2017, given the attitude of the people who used to apathetic so that the presence of local political parties became one thing awaited by the community. The crisis of trust that has been happening to national political parties has become one of the benchmarks for people to participate in the implementation of local democracy through the emergence of local political parties in Aceh.

However, expectations of the community against local political parties are not so much seen in recent years. In addition, to the confidence crises occurring in national political parties, local party elites are still more preoccupied with inner issues that occur within local party gangs and this identity is also regarded as a negative aspect in local political parties. The regulatory conflicts that exist between local party political elites are one of the causes of local party performance that should be more focused on implementing the functions of local political parties themselves. Besides, Aceh which is still in the post-conflict transition period is also one of the reasons for local political parties in carrying out its functions in Aceh. Thus, the existence of political parties can be said as a pillar for the implementation of democratization in Aceh although its functions are not still maximum with the implementation of Islamization toward local political parties. 


\section{References}

Alwy, Sudarman, and Reza Febriandi. 2018. "Partisipasi Politik Santri pada Pemilihan Bupati Aceh Barat 2017.” Jurnal Public Policy 3(2): 23747.

DOI: https://doi.org/10.35308/jpp.v3i2.72

Asfar, Muhammad. 2006. Mendesain Managemen Pilkada. Surabaya: PusDeHAM and Pustaka Eureka.

Aspinall, Edward and Wawan Mas'udi. 2017. "The 2017 Pilkada (Local Elections in Indonesia: Clientelism, Programmatic Politics and Social Networks." Contemporary Southeast Asia: A Journal of International and Strategic Affairs 39(3): 417-26.

Budiardjo, Miriam. 2008. Dasar-Dasar Ilmu Politik. Jakarta: PT Gramedia Pustaka Utama.

Crick, Bernard. 1959. The American Science of Politics: Its Origins and Conditions. London: University of California Press.

Cwalina, Wojciech, Andrzej Falkowski, and Bruce I. Newman 2010. "Towards the Development of a Cross-Cultural Model of Voter Behavior: Comparative Analysis of Poland and the US." European Journal of Marketing 44(3/4): 351-68.

DOI: https://doi.org/10.1108/03090561011020462

Dahl, Robert A. 1961. "The Behavioral Approach in Political Science: Epitaph for a Monument to a Successful Protest." The American Political Science Review 55(4): 763-72.

Firmanzah. 2007. Marketing Politik. Jakarta: Yayasan Obor Indonesia.

Hayward, Clarissa Rile and Ron Watson. 2010. "Identity and Political Theory." Washington University Journal of Law EF Policy 33: 9-41.

Housholder, Elizabeth E. and Heather L. LaMarre. 2014. "Facebook Politics: Toward a Process Model for Achieving Political Source Credibility Through Social Media." Journal of Information Technology and Politics 11(4): 368-82.

DOI: https://doi.org/10.1080/19331681.2014.951753 
Husna, Asmaul. 2017. "Analisis Political Branding Calon Kepala Daerah Dalam Pilkada Aceh 2017." Jurnal Komunikasi Global 6(1): 56-73.

Januar, Eka. 2018. "Dinamika Money Politics pada Pemilukada Aceh 2017." Al-Ijtima'i: International Journal of Government and Social Science 4(1): 49-61.

Jati, Wasisto Raharjo. 2012. "Ulama dan Pesantren dalam Dinamika Politik dan Kultur Nahdlatul Ulama." Ulul Albab: Jurnal Studi Islam 13(1): 95-111.

DOI: http://dx.doi.org/10.18860/ua.v0i0.2377

LaMarre, Heather L. and Yoshikazu Suzuki-Lambrecht. 2013. "Tweeting Democracy? Twitter as a Voter Mobilization Strategy for Congressional Campaigns." Public Relations Review 39(4): 360-8. DOI: https://doi.org/10.1016/j.pubrev.2013.07.009

Meyer, Thomas M. and Daniel Strobi. 2016. "Voter Perceptions of Coalition Policy Positions in Multiparty Systems." Electoral Studies 41: 80-91.

DOI: https://doi.org/10.1016/j.electstud.2015.11.020

Nur, Muhammad, Usman, and Irwan Safwadi. 2018. "Dinamika Politik Partai Lokal dan Nasional pada Pemilukada di Aceh, Tahun 2017." Jurnal Humaniora 2(2): 140-9.

DOI: https://doi.org/10.30601/humaniora.v2i2.61

"Pilkada 2017 Lebih Baik dari Sebelumnya 2017. 2017." http://aceh.tribunnews.com/2017/02/28/pilkada-2017-lebih-baikdari-sebelumnya (June 8, 2018)

Surbakti, Ramlan. 1992. Memahami Ilmu Politik. Jakarta: PT.Grasindo.

Sweetser, Kaye D. 2011. "Digital political public relations." In Political Public Relations Principles and Applications, eds. Jesper Stromback and Spiro Kiousis. New York: Routledge, 293-313.

Tiro, Hasan Muhammad. 1999. Demokrasi Untuk Indonesia. Jakarta: Teplok Press.

Varma, SP. 2010. Teori Politik Modern. Jakarta: PT RajaGrafindo Persada. 
Widjaja, Haw. 2005. Penyelenggaraan Otonomi di Indonesia. Jakarta: PT Rajagrafindo.

Ulul Albab Volume 20, No.2 Tahun 2019 